\title{
COORDINATION BEHAVIOUR OF 2- HYDROXYBENZOIC ACID HYDRAZIDE TOWARDS NICKEL (II) AND COBALT(II): SPECTROSCOPIC INVESTIGATION
}

\author{
Purnima Bajracharya and Sabita Shrestha \\ Central Department of Chemistry, \\ Tribhuvan University, Kirtipur, Kathmandu, Nepal.
}

\begin{abstract}
Four coordinated Nickel and six coordinate Cobalt complexes of type [Ni $\left.(\mathrm{HBH})_{2}\right]$. 2Cl, and $\left.\mathrm{Co}(\mathrm{HBSH})_{2} \mathrm{Cl}_{2}\right] \mathrm{Cl}_{2} 2 \mathrm{H}_{2} \mathrm{O}$ [2- $\mathrm{HBH}=2-\mathrm{Hydroxybenzoic}$ acid hydrazide] respectively were synthesized. The coordination behavior of 2-HBH in complexes have been suggested on the basis of analytical and spectroscopic techniques, where the ligand is coordinating to metal through oxygen of carbonyl and nitrogen of terminal $\mathrm{NH}_{2}$ group. All the complexes are coloured and non-hygroscopic. The compositions of complexes were established on the basis of various analytical procedures. The molar conductance value shows 1:1 electrolyte in Co(II) complex and 1:2 in Ni(II) complex. The electronic spectral studies showed the square planner geometry around $\mathrm{Ni}(\mathrm{II})$ and octahedral geometry around the $\mathrm{Co}(\mathrm{II})$ ion. The optical band gap energy of complexes was derived from electronic spectra the value of which underlies the range of semiconductor materials
\end{abstract}

Keywords: 2-Hydroxybenzoic acid hydrazide complexes; Synthesis; spectral studies; Band gap.

\section{INTRODUCTION}

2-Hydroxybenzoic acid hydrazide, a type of acyl hydrazines or hydrazides, is derivative of hydrazine, which is obtained by replacement of one of $\mathrm{H}$-atoms in hydrazine by an acyl ( $\mathrm{RCO}, \mathrm{R}=\mathrm{C}_{6} \mathrm{H}_{5} \mathrm{OH}$, for $\left.2-\mathrm{HBH}\right)$ group $^{1,} 2$. Hydrazides can be further classified by atom attached to the oxygen: carbohydrazides $\left(\mathrm{R}-\mathrm{C}(=\mathrm{O})-\mathrm{NH}-\mathrm{NH}_{2}\right)$,

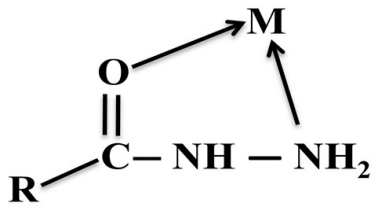

(a) sulfonohydrazides $\left(\mathrm{R}-\mathrm{S}(=\mathrm{O})_{2}-\mathrm{NH}-\mathrm{NH}_{2}\right)$ and phosphonic dihydrazides $\left(\mathrm{R}-\mathrm{P}(=\mathrm{O})\left(-\mathrm{NH}-\mathrm{NH}_{2}\right)_{2}{ }^{3}\right.$ etc. Hydrazides are rather reactive substance; they are bidentate ligands. Hydrazide form complexes in either amide (a) or imide (b) forms. As shown in Fig. 1. Hydrazides successfully provide various active potential donors sites, namely $\mathrm{C}=\mathrm{O}$, $\mathrm{N}-\mathrm{H}$, and $\mathrm{NH}_{2}{ }^{4}$.

Figure 1: (a) Amide and (b) Imide form

Hydrazides, its analogues and metal complexes have continued to attract interest because of their ability to readily coordinate to a variety of elements particularly transition metals using carbonyl oxygen and amino nitrogen as donor atoms. Apart from the interesting structural chemistry, hydrazides are known to include an essential category of biologically active organic compounds. These hydrazides and their condensation

Author for Correspondence: Sabita Shrestha, Central Department of Chemistry, Tribhuvan University, Kirtipur, Kathmandu, Nepal.

Email: shresthasabita@hotmail.com

Received: 10 Nov 2020; First Review: 25 Nov 2020; Second Review: 14 Dec 2020; Accepted: 17 Dec 2020.

Doi: https://doi.org/10.3126/sw.v14i14.34981 
products possess a wide range of applications such as: antibacterial activity ${ }^{5}$, tuberculostatic properties $^{6}$, HIV inhibitors $^{7}$, pesticidal ${ }^{8}$, antifungal ${ }^{9}$. Some of the hydrazides and analogous hydrazones are psychopharmacological agent such as monoamine oxidase (MAO) inhibitor and serotonin antagonists ${ }^{10}$. Similarly hydrazides and its metal complexes, have found applications in the industry as metal extractants, in wastewaters, polymer stabilization and ion exchange problems ${ }^{11}$. Hydrazine and hydrazones have also been used in the determination of various metal ions by spectrophotometry, conductometry ${ }^{12}$.

The present works aims to study the coordination behavior of 2-HBH towards transition metals (Nickel and Cobalt).

The composition of complexes was established on the basis of various analytical procedures. The coordination behavior and structures of the synthesized complexes were studied from infrared and electronic spectral studies.

Further, the study aims to growing up numbers of semiconductors which may be used as potential materials for harvesting solar radiation in solar cell applications and fabrications of many electronic devices. For this purpose, the energy gap of complexes has been determined to describe their electronic properties.

\section{EXPERIMENTAL METHODS}

\section{Starting Materials}

Transition metal salts $\left(\mathrm{MX}_{2} \cdot \mathrm{nH}_{2} \mathrm{O}\right.$, where $\mathrm{M}=\mathrm{Ni}, \mathrm{Co}$, $\mathrm{X}=\mathrm{Cl}$ ) were obtained from Merck. Methyl hydrazine is of Nike Company. The solvent ethanol were purchased from Qualigens Chemical Company and used without further purifications.

\section{Synthesis of Ligand, 2-Hydroxybenzoic Acid Hydrazide}

The ligand 2- $\mathrm{HBH}, \mathrm{C}_{7} \mathrm{H}_{8} \mathrm{~N}_{2} \mathrm{O}_{2}$ was prepared by refluxing together ethanolic solutions of Methyl 2-hydroxybenzoate $(26 \mathrm{~mL})$ with hydrazine monohydrate $(12 \mathrm{~mL})$ in $1: 1.2$ mole ratio for about 3 to 4 hours and leaving the solution overnight ${ }^{13}$. The product formed was filtered and thoroughly washed with distilled water. Thus obtained hydrazide was recrystallized from ethanol (Scheme.1).

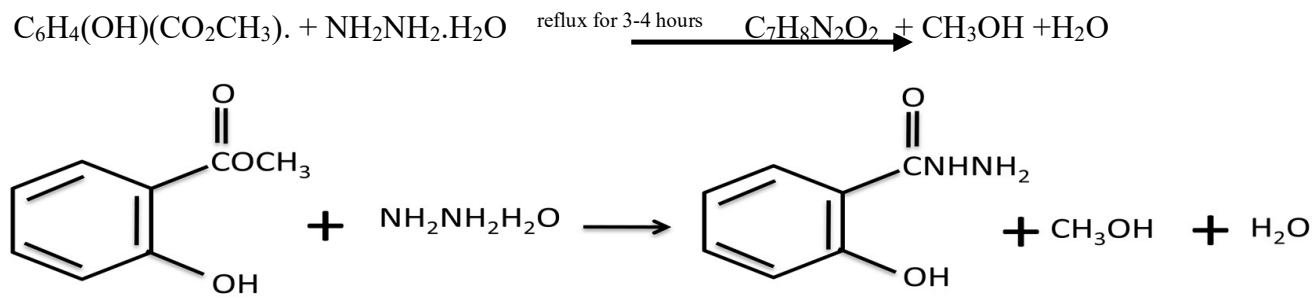

Scheme 1: Synthesis of 2-Hydroxybenzoic acid hydrazide

The yield was found to be $65 \%$ and the m. p. was found to be $146^{\circ} \mathrm{C}$. The ligand, 2-hydroxybenzoic acid hydrazide is soluble in ethanol, methanol, conc. $\mathrm{H}_{2} \mathrm{SO}_{4}, \mathrm{HNO}_{3}$ and polar solvents such as DMF and DMSO.

\section{Characterization of Ligand}

The structure of the prepared ligand (Fig. 2) was established on the basis of infrared data. The analytical data of ligand is shown in Table 1.

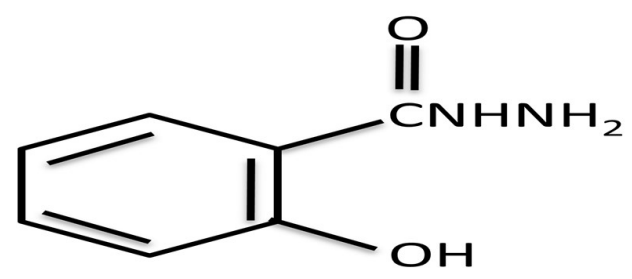

Figure 2: 2-Hydroxybenzoic acid hydrazide 
Table 1. Analytical data of ligand 2-hydroxybenzoic acid hydrazide (HBH)

\begin{tabular}{|l|l|l|l|}
\hline $\begin{array}{l}\text { Name of ligand, } \\
\text { Formula, Mol.wt. }\end{array}$ & Colour & $\begin{array}{l}\text { Yield } \\
(\%)\end{array}$ & $\begin{array}{l}\text { M.P } \\
\left({ }^{\circ} \mathrm{C}\right) \\
\text { Lit. } \\
\left({ }^{\circ} \mathrm{C}\right)\end{array}$ \\
\hline $\begin{array}{l}\text { 2-Hydroxybenzoic } \\
\text { acid hydrazide } \\
\mathrm{C}_{7} \mathrm{H}_{8} \mathrm{~N}_{2} \mathrm{O}_{2}, 152\end{array}$ & $\begin{array}{l}\text { Off-white } \\
\text { Crystalline } \\
\text { powder }\end{array}$ & $70 \%$ & 146 \\
& & & $(146)^{*}$ \\
${ }^{*}$ Ref. 13 & & & \\
\hline
\end{tabular}

\section{Synthesis of Complexes}

The $\mathrm{Ni}(\mathrm{II})$ and $\mathrm{Co}(\mathrm{II})$ complex were synthesized by reacting $50 \mathrm{~mL}$ ethanolic solution containing each of $\mathrm{NiCl}_{2} \cdot 6 \mathrm{H}_{2} \mathrm{O}$ and $\mathrm{CoCl}_{2} \cdot 6 \mathrm{H}_{2} \mathrm{O}$ with ligand 2- $\mathrm{HBH}$. The ligand to metal ratio is 1:2 molar ratio. It was refluxed for one hour. On concentrating the reaction solution to one third of the volume on water bath the complexes formed in solution slowly crystallized at room temperature upon standing for 24 hours. Coloured compound was obtained which was filtered and dried in desiccator over calcium chloride at room temperature ${ }^{13}$.

\section{Characterization of Complexes}

The chemical and physical methods employed for coordination behavior of ligand and structural investigations of the complexes in the present work are, (i) metal estimation (ii) ligand estimation (iii) dehydration study (iv) anion estimation (v) molar conductance (vi) electronic spectroscopy and (vi) infrared spectroscopy.

\section{Analysis of Complex:}

The complexes were analyzed for their metal content gravimetrically ${ }^{14}$. For this complex was accurately weighed in silica crucible and digested by allowing it to burn directly first in low heat and then to strong heat where complex changed to oxide and left it to cool in desiccators. Then from the weight of oxide, amount of metal was calculated.

The ligand content of the complexes was estimated by calibration curve method ${ }^{15}$. In this method, a weighed quantity of the complex was dissolved in $20 \mathrm{~mL}$ of $1: 1$ $\mathrm{HCl}$ and few drops of methyl orange was added then titrated against the standard solution of $0.1 \mathrm{~N} \mathrm{KBrO}_{3}$. The ligand content adjudged from a calibration curve which was constructed by plotting the data of at least five sets of titrations where, in each case, a varying amount of the ligand was dissolved in $20 \mathrm{~mL}$ of $1: 1 \mathrm{HCl}$ and the solution was titrated against a standard solution of $\mathrm{KBrO}_{3}$.

The chloride content in the complexes was determined gravimetrically as silver chloride ${ }^{14}$.

The water content in complex was determined from dehydration study. In complexes two types of water molecules are present: lattice water and coordinated water. Coordinated water is directly bonded to central metal and lattice water is found somewhere in the lattice of complex. Generally, the lattice water will be lost at a lower temperature than that of coordinated water. Lattice water is lost around $60-120^{\circ} \mathrm{C}$, whereas the loss of coordinated water requires about $150{ }^{\circ} \mathrm{C}^{17}$. Dehydration studies of the complexes were done by heating the samples in two stages $\left(110^{\circ} \mathrm{C}\right.$ and $\left.150^{\circ} \mathrm{C}\right)$ for one hour and recording the loss of weight at each stage. The data were used for calculating the amounts of lattice and coordinated water molecules ${ }^{15}$.

\section{Physico-Chemical Measurements}

Solution state molar conductance of complex is obtained from the measured value of specific conductance. It helps to confirm the electrolytic nature and the number of anion present outside the coordination sphere.

Specific conductance $(\mathrm{k})$ related to the resistance $(\mathrm{R})$ by the relation,

$$
\mathrm{k}=\frac{\text { Cell Constant }}{\mathrm{R}}
$$

Molar conductance $\Lambda_{\mathrm{m}}$ can be calculated using the relation.

$$
\Lambda_{m}=\frac{1000 \mathrm{~K}}{\mathrm{C}}
$$

where $\mathrm{C}$ is the concentration in $\mathrm{ML}^{-1}$.

Infrared spectra of the ligand and its complexes were obtained on $\mathrm{KBr}$ pellets in $4000-400 \mathrm{~cm}^{-1}$ range in FTIR IR Prestige- 21 Shimadzu. Electronic absorption spectra were obtained in DMSO solution in USB-2000 Photonix.

\section{RESULTS AND DISCUSSION}

\section{General Behaviour}

The synthesized complexes are coloured and nonhygroscopic. The analytical data of complexes are given in Table 2. The molar conductance of $\mathrm{Ni}(\mathrm{II})\left(10^{-3} \mathrm{M}\right.$ in DMSO) is found to be $159 \Omega^{-1} \mathrm{~cm}^{2}$ mole ${ }^{-1}$ showing presence of two chloride ions outside the coordination sphere. Similarly the molar conductance of Co(II) complex 
$\left(10^{-3} \mathrm{M}\right.$ in DMSO) is found to be $54 \Omega^{-1} \mathrm{~cm}^{2} \mathrm{~mole}^{-1}$ showing 1:1 electrolytic behavior i.e. presence of one chloride ion outside the coordination sphere ${ }^{16}$. The dehydration studies of Nickel complex didn't show any weight loss at temperature $110{ }^{\circ} \mathrm{C}$ and at $150{ }^{\circ} \mathrm{C}$ which indicates that complex does not contain any lattice as well as coordinated water molecules. The dehydration studies of cobalt complex showed weight loss at temperature $110^{\circ} \mathrm{C}$ which indicates the presence of two lattice water molecules and no weight loss at $150{ }^{\circ} \mathrm{C}$ which showed that the complex didn't contain any coordinated water molecules. The composition of complexes were established on the basis of analytical data and molar conductance value which correspond to composition $\left[\mathrm{Ni}(2-\mathrm{HBH})_{2}\right] 2 \mathrm{Cl}$ for $\mathrm{Ni}(\mathrm{II})$ complex and $\left[\mathrm{Co}(2-\mathrm{HBH})_{2} \mathrm{Cl}_{2}\right] \mathrm{Cl}_{2} 2 \mathrm{H}_{2} \mathrm{O}$ for $\mathrm{Co}(\mathrm{II})$ complex.

Table 2. Analytical data of complexes

\begin{tabular}{|c|c|c|c|c|c|c|}
\hline $\begin{array}{c}\text { Complex, colour, } \\
\text { Yield (\%) }\end{array}$ & Empirical formula (formula wt.) & $\begin{array}{c}\text { M.P } \\
\left({ }^{\circ} \mathrm{C}\right)\end{array}$ & $\begin{array}{c}\text { Metal } \\
(\%)\end{array}$ & $\begin{array}{c}\text { Ligand } \\
(\%)\end{array}$ & $\begin{array}{c}\text { Water } \\
(\%)\end{array}$ & $\begin{array}{c}\text { Chloride } \\
(\%)\end{array}$ \\
\hline $\left.\mathrm{Ni}(2-\mathrm{HBH})_{2}\right] .2 \mathrm{Cl}$ & $\mathrm{Ni}^{2}\left[\mathrm{C}_{7} \mathrm{H}_{8} \mathrm{O}_{2} \mathrm{~N}\right]_{2} .2 \mathrm{Cl}$ & 160 & 14.70 & 71.08 & 0 & 17.00 \\
Light green $(78 \%)$ & $(433)$ & & $(13.62)$ & $(70.20)$ & & $(16.16)$ \\
\hline $\left.\mathrm{Co}(2-\mathrm{HBH})_{2} \mathrm{Cl}_{2}\right] \mathrm{Cl}$ & $\mathrm{Co}\left[\left(\mathrm{C}_{7} \mathrm{H}_{8} \mathrm{O}_{2} \mathrm{~N}_{2}\right)_{2} \mathrm{Cl}_{2}\right] . \mathrm{Cl}_{2} 2 \mathrm{H}_{2} \mathrm{O}$ & 235 & 12.15 & 59.48 & 8.0 & 21.45 \\
$.2 \mathrm{H}_{2} \mathrm{O}$ & $(504)$ & & $(11.70)$ & $(60.31)$ & $(7.14)$ & $(20.83)$ \\
light violet $(60 \%)$ & & & & & \\
\hline
\end{tabular}

The value inside parenthesis is calculated value and outside is experimental value.

\section{Infrared Spectral Study}

IR spectroscopy is one of the most common spectroscopic techniques used for the structural elucidation of metal complex. The coordination behavior of ligand to the metal ion has been judged by comparison of infrared spectra of complexes with free ligand. A few significant bands have been selected (Table 3) to observe the effect on ligand vibration in the complexes.

Table 3. Important IR spectral data $\left(\mathrm{cm}^{-1}\right)$

\begin{tabular}{|c|c|c|c|c|c|}
\hline Ligand/complex & $v(\mathrm{OH})+v(\mathrm{NH})$ & Amide I & Amide II & Amide III & $v(\mathrm{~N}-\mathrm{N})$ \\
\hline $2-\mathrm{HBH}$ & 3265 & 1635 & 1585 & 1350 & 995 \\
\hline$\left[\mathrm{Ni}(2-\mathrm{HBH})_{2}\right] \cdot 2 \mathrm{Cl}$ & 3317 & 1605 & 1550 & 1360 & 1040 \\
\hline $2 \mathrm{Co}\left[(2-\mathrm{HBH})_{2} \mathrm{Cl}_{2}\right] \cdot \mathrm{Cl} \cdot 2 \mathrm{H}_{2} \mathrm{O}$ & 3303 & 1605 & 1550 & 1365 & 1034 \\
\hline
\end{tabular}

In the spectrum of ligand 2-HBH, the absorption band $3265 \mathrm{~cm}^{-1}$ is attributed to $v(\mathrm{OH})+v(\mathrm{NH})$. The shifting of $v(\mathrm{O}-\mathrm{H}, \mathrm{N}-\mathrm{H})$ band in complexes indicate the bonding from terminal $-\mathrm{NH}_{2}$ group to the metal. The amide (I, II, III) bands characteristics of the $>\mathrm{CONH}-$ group in ligand $\mathrm{RCONHNH}_{2}\left(\mathrm{R}=\mathrm{C}_{6} \mathrm{H}_{5} \mathrm{OH}\right)$ were observed at 1635,1585 and $1350 \mathrm{~cm}^{-1}$ respectively ${ }^{17}$ indicate that the ligand exists in the keto form in the solid state ${ }^{18}$. In complexes these bands observed at 1605, 1550, $1360 \mathrm{~cm}^{-1}$ in $\mathrm{Ni}(\mathrm{II})$ complex and 1605, 1550, $1365 \mathrm{~cm}^{-1}$ in $\mathrm{Co}$ (II) complex. The amide bands are used for judging the coordination of carbonyl group in complex. The amide $\mathrm{I}, \mathrm{v}(\mathrm{C}=\mathrm{O})$, amide II, $\delta(\mathrm{N}-\mathrm{H})$ bands were found to undergo bathochromic shifts and the amide III band, $v(\mathrm{C}-\mathrm{N})$ undergo a hypsochromic shift suggesting that the coordination occurred through the oxygen of the carbonyl group and nitrogen of terminal $\mathrm{NH}_{2}$ group ${ }^{15}$.

A weak band, (N-N) vibration in ligand is observed at 995 $\mathrm{cm}^{-1}$. This vibration was shifted to higher frequency (1040 $\mathrm{cm}^{-1}$ in $\mathrm{Ni}(\mathrm{II})$ complex and $1034 \mathrm{~cm}^{-1}$ in $\mathrm{Co}(\mathrm{II})$ complex) suggesting coordination through nitrogen atom of hydazide moiety ${ }^{19}$. 
The non-ligand bands occurring at $494 \mathrm{~cm}^{-1}$ for $\mathrm{Co}$ (II) and $503 \mathrm{~cm}^{-1}$ for $\mathrm{Ni}(\mathrm{II})$ have been assigned to $v(\mathrm{M}-\mathrm{O})$. Another non-ligand band at $310 \mathrm{~cm}^{-1}$ in $\operatorname{Co}(\mathrm{II})$ and $350 \mathrm{~cm}^{-1}$ in $\mathrm{Ni}(\mathrm{II})$ is assigned to $v(\mathrm{M}-\mathrm{N})^{19}$.

\section{Electronic Spectral Study}

The electronic absorption spectra are often very useful in evaluation of results furnished by other methods of structural investigation. Electronic spectra of and Co(II) and $\mathrm{Ni}(\mathrm{II})$ complexes are given in Fig. 3(a) and (b) respectively. The spectra show few bands in visible region of electromagnetic spectrum.
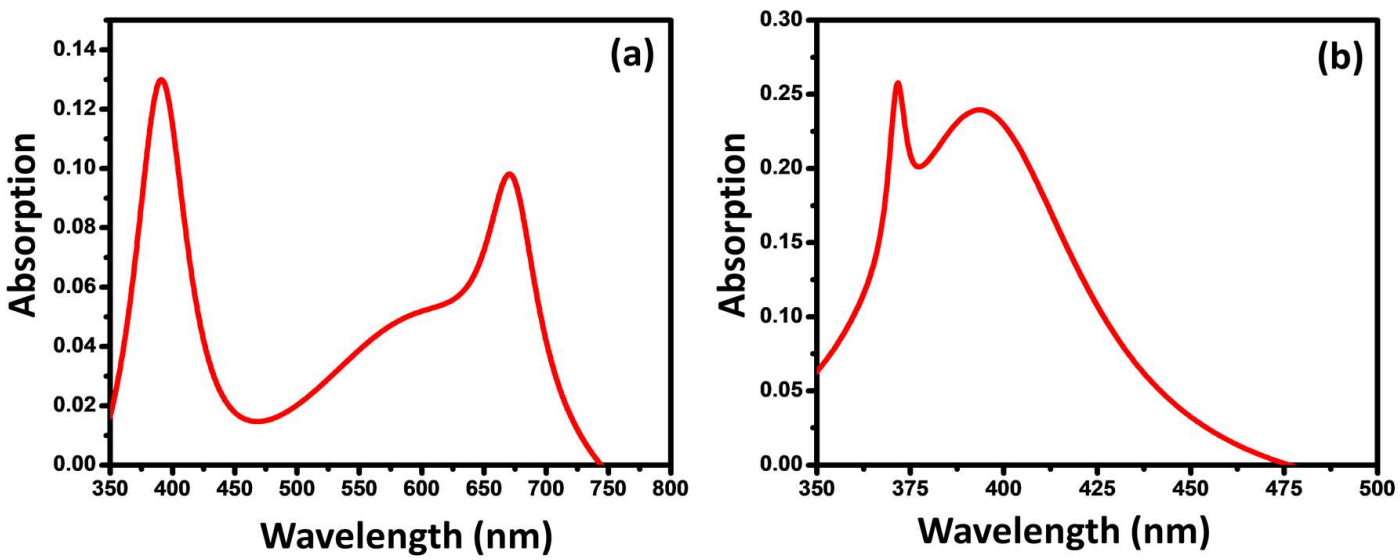

Figure 3: Electronic spectra of (a) $\left.\mathrm{Co}(2-\mathrm{HBH})_{2} \mathrm{Cl}_{2}\right] \mathrm{Cl} .2 \mathrm{H}_{2} \mathrm{O}$ (b) $\left[\mathrm{Ni}(2-\mathrm{HBH})_{2}\right] .2 \mathrm{Cl}$

The $\mathrm{Co}(\mathrm{II})$ in complex is in $\mathrm{d}^{7}$ configuration and the corresponding ground state is ${ }^{4} \mathrm{~F}$ and ${ }^{4} \mathrm{P}$ is spin allowed excited state. The band in the region $\sim 14900 \mathrm{~cm}^{-1}$ is attributed to ${ }^{4} \mathrm{~T}_{1 \mathrm{~g}}(\mathrm{~F}) \rightarrow{ }^{4} \mathrm{~T}_{2 \mathrm{~g}}(\mathrm{~F})$ transition in consistent with an octahedral geometry around $\mathrm{Co}(\mathrm{II})$ ion. The peak $\sim 17300 \mathrm{~cm}^{-1}$ may be due to ${ }^{4} \mathrm{~T}_{1 \mathrm{~g}}(\mathrm{~F}) \rightarrow{ }^{4} \mathrm{~T}_{1 \mathrm{~g}}(\mathrm{P})$ transition. The high energy transition ${ }^{4} \mathrm{~T}_{1 \mathrm{~g}}(\mathrm{~F}) \rightarrow{ }^{4} \mathrm{~A}_{2 \mathrm{~g}}$ (F) may be overlap by strong charge transfer transition occur at 25700 $\mathrm{cm}^{-1}$.

For $\mathrm{Ni}$ (II) complex the band in the region $\sim 25000 \mathrm{~cm}^{-1}$ is attributed to ${ }^{1} \mathrm{~A}_{1 \mathrm{~g}} \rightarrow{ }^{1} \mathrm{~A}_{2 \mathrm{~g}}$ transition in consistent with a square planar geometry around Ni(II) ion. Another band at $\sim 26000 \mathrm{~cm}^{-1}$ may be due to transition ${ }^{1} \mathrm{~A}_{1 \mathrm{~g}} \rightarrow{ }^{1} \mathrm{~B}_{1 \mathrm{~g}}{ }^{20}$.

\section{Determination of Optical Band Gap Energy}

The gap between valence band and conduction band is called band gap. The band gap is different in conductor, semiconductor and insulator. In the same matter band gap is changed with change in size of materials. The band gap energy of complexes was derived from electronic absorption spectroscopy.

From the absorption spectroscopy plot, the band gap of materials can be estimated using the Tauc formula

$$
\alpha h v=\mathrm{A}\left(h v-\mathrm{E}_{\mathrm{g}}\right)^{\mathrm{m}}
$$

Where $h v$ is the incident photon energy $(\mathrm{eV}), \mathrm{A}$ is energy independent constant, $\mathrm{E}_{\mathrm{g}}$ is the bandgap $(\mathrm{eV})$ of the material and $\mathrm{m}$ is an exponent which has value $1 / 2$, and 2 for direct and indirect band gap. The value of $\alpha$ is obtained from spectra. The Fig. 4 (a) and (b) shows the graph plotted between $(\alpha h v)^{2}$ and $h v$ of $\mathrm{Co}(\mathrm{II})$ and $\mathrm{Ni}(\mathrm{II})$ complex respectively. From graph the direct band gap was found by extrapolating the linear portion of the curve to $(\alpha h v)^{2}=0$ and values of direct optical band gap energy, $\mathrm{E}_{\mathrm{g}}$ was determined. 

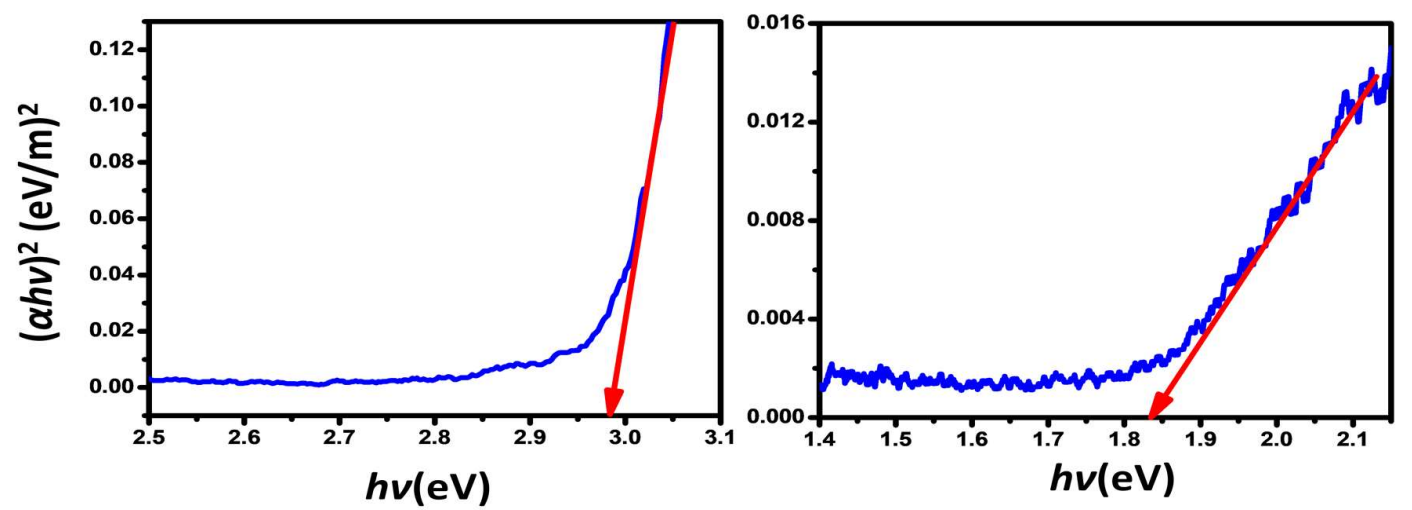

Figure 4: The plots of $(\alpha \mathrm{hv})^{2}$ vs. hv of (a) $\mathrm{Co}$ (II) and (b) Ni(II) complex.

The value of $E_{\mathrm{g}}$ from graph was found to be $2.98 \mathrm{eV}$ and $1.84 \mathrm{eV}$ for $\mathrm{Co}(\mathrm{II})$ and $\mathrm{Ni}(\mathrm{II})$ and complexes respectively. The obtained band gap energy values suggest that these complexes are semiconductors and lie in the same range of highly efficient photovoltaic materials. So, the present compounds could be considered potential materials for harvesting solar radiation in solar cell applications ${ }^{21}$.

\section{CONCLUSIONS}

$\mathrm{Co}(\mathrm{II})$ and $\mathrm{Ni}(\mathrm{II})$ complexes derived from 2hydroxybenzoic acid hydrazide have been isolated in pure form. The ligand and its $\mathrm{Ni}$ (II) and $\mathrm{Co}$ (II) complexes are prepared by reflux method. The different analytical data and molar conductance value indicate that the $\mathrm{Co}$ (II) and $\mathrm{Ni}(\mathrm{II})$ complexes have composition $\mathrm{Co}(2-\mathrm{HBH})_{2}$ $\left.\mathrm{Cl}_{2}\right] \mathrm{Cl} \cdot 2 \mathrm{H}_{2} \mathrm{O}$ and $\left[\mathrm{Ni}(2-\mathrm{HBH})_{2}\right] 2 \mathrm{Cl}$ respectively. The infrared data show that the ligand 2-HBH coordinated to the central metal ion through $\mathrm{C}=\mathrm{O}$ and terminal $\mathrm{NH}_{2}$. The electronic spectra suggest octahedral geometry around the Co (II) ion and square planar geometry around the $\mathrm{Ni}$ (II) ion in the complex. The direct band gap energy (Eg) for complexes lies in the range of semiconductor materials. Based on the above conclusions following tentative structure have been proposed for $\mathrm{Co}$ (II) and $\mathrm{Ni}$ (II) complexes 2-Hydroxybenzoic acid hydrazide (Fig. 5).

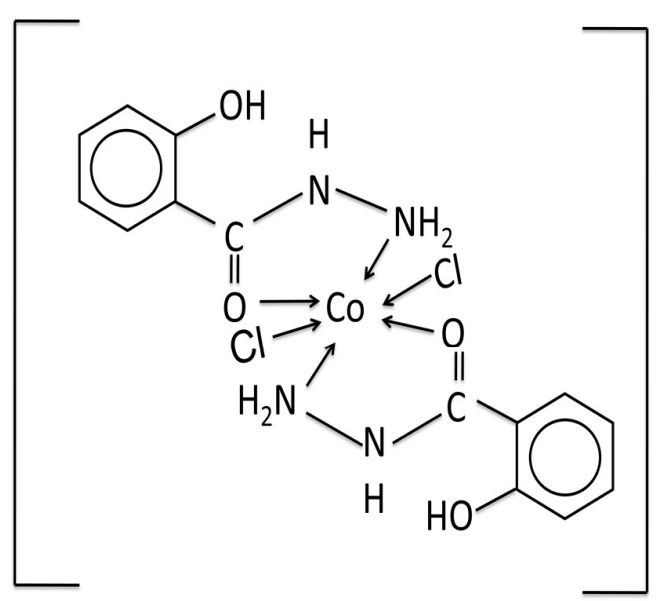

(a)
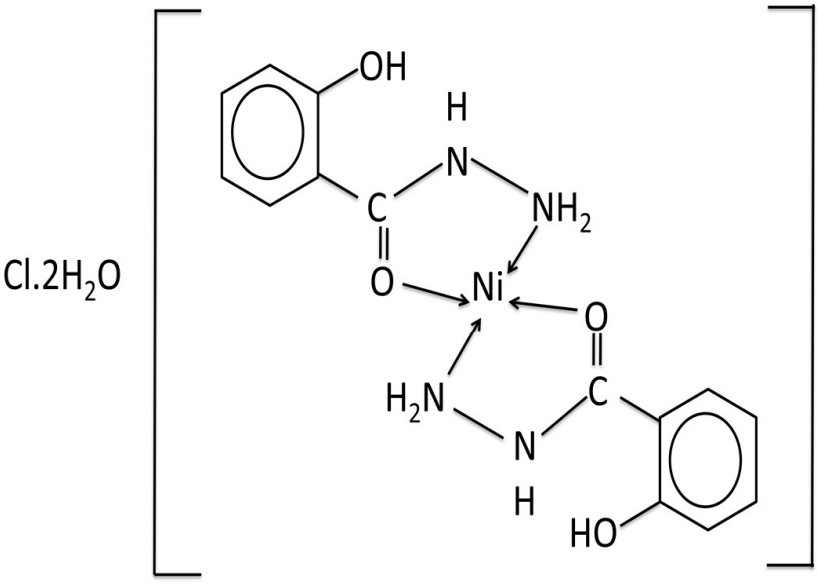

(b)

Figure 5: Proposed structure for (a) $\left.\mathrm{Co}(2-\mathrm{HBH})_{2} \mathrm{Cl}_{2}\right] \mathrm{Cl} .2 \mathrm{H}_{2} \mathrm{O}$ (b) $\left[\mathrm{Ni}(\mathrm{HBH})_{2}\right] .2 \mathrm{Cl}$ 


\section{ACKNOWLEDGEMENTS}

We are very thankful to Central Department of Chemistry, T. U., for laboratory facility; Prof. Dr. Shankar Shrestha, Patan Multiple College, for recording the electronic spectra and Mr. Keshav Paudel, Natural Product Development Division, Thapathali for recording IR spectra of the complexes.

\section{REFERENCES}

1. Audrieth, L. F. and Ogg, B. A.1951. The Chemistry of hydrazine, Wiley, New York.

2. Miller, I. T. and Springall, H. D. 1966. The organic chemistry of nitrogen ( $3^{\text {rd }}$ Edn.), Clarendon Press, Oxford.

3. IUPAC, Compendium of chemical terminology, 1977. (2nd Edn.) (The "Gold Book"), Online corrected version: (2006) "Hydrazides".

4. Majumdar, P., Pati, A., Patra, M., Behera, R. K. and Behera, A. K. 2014. Acid hydrazides, potent reagents for synthesis of oxygen-, nitrogen-, and/or sulfur-containing heterocyclic rings. Chemical Review. 114: 2942-2977.

5. Rollas, S., Gulerman, N. and Erdeniz, H. 2002. Synthesis and antimicrobial activity of some new hydrazones of 4-fluorobenzoic acid hydrazide and 3-acetyl-2,5-disubstituted-1,3,4-oxadiazolines. Farmaco. 57(2): 171-174

6. Pavan, F. R., Maia, PI. Da. S., Leite, SRA., Deflon, V. M., Batista, A. A., Sato, D. N., Franzblau, S. G. and Leite, CQF. 2010. Thiosemicarbazones, semicarbazones, dithiocarbazates and hydrazide/hydrazones: anti-Mycobacterium tuberculosis activity and cytotoxicity. European Journal of Medicinal Chemistry. 45(5): 1898-1905.

7. Marastoni, M., Baldisserotto, A., Trapella, C., McDonald, J., Bortolotti, F.and Tomatis, R. 2005. HIV protease inhibitors: synthesis and activity of N-aryl-N'-hydroxyalkyl hydrazide pseudopeptides. European Journal of Medicinal Chemistry. 5: 445451 .

8. Tabanca, N., Ali, A., Bernier, UR., Khan, I., KocyigitKaymakciogl, B., Oruc-emre, E., Unsalan, S. and Rollas, S. 2013, Biting deterrence and insecticidal activity of hydrazide-hydrazones and their corresponding 3-acetyl-2, 5-disubstituted-2, 3-dihydro-1, 3, 4-oxadiazoles against aedes aegypti. Pest Management Science. 69(6): 703- 708 .

9. Turan-Zitouni, G., Altintop, MD., Ozdemir, A., Demirci, F., Mohsen, UA. and Kaplancikli, ZA. 2013. Synthesis and Antifungal activity of new hydrazide derivatives. Journal of Enzyme Inhibition and Medicinal Chemistry. 28(6): 1211-1216.

10. Kumar, A., Jakhar, A. and Makrandi, J. K. 2012. A highly efficient solvent free synthesis of hydrazides using grinding technique. Heterocyclic Letter. 2(4): 401-404.

11. Adekunle, F. A., Woods, J. A. O., Adeoye, L. O., Onawumi, O. O, Odunola, O. A., Department of Pure and Applied Chemistry,
Report. Department of Chemistry, University of Ibadan, Ibadan, Nigeria.

12. Shrestha, S. 1999. Complexes of trivalent yttrium and lanthanides with acyl hydrazide schiff base, $\mathrm{Ph}$. D. Thesis, Banaras Hindu University, Varanasi, India.

13. Shrestha, S. 2016. Nickel(II) complex of hydrazide schiff base; salicylaldehyde salicyloyl hydrazone: synthesis and characterization. Journal of Nepal Chemical Society. 35(1): 53-60.

14. Vogel, A. I. 1998. Text Book of Quantitative Inorganic Analysis ( $4^{\text {th }}$ Edn.), ELBS, London.

15. Narang, K. K., Rao, T. R., Shrestha, S. and Shrestha, S. 2000 Synthesis, characterization, thermal and electrical properties of yttrium(iii) and lanthanide(iii) complexes of salicylaldehyde benzoyl hydrazone. Synthesis and Reactivity in Inorganic and Metal-Organic Chemistry. 30(5): 931-954.

16. Geary, W. J. 1971. The use of conductivity measurements in organic solvents for the characterization of coordination compounds. Coordination Chemistry Review. 7: 81.

17. Silva, Z. S., Botta, S. B., Ana, P. A., França, C. M., Fernandes, K. P. S., Mesquita-Ferrari, R. A., Deana ,A. and Bussadori, S. K. 2015.Effect of papain-based gel on type I collagen - spectroscopy applied for microstructural analysis. Scientific Report. 5: 11448 (17).

18. Rao, C. N. R.1963. Chemical application of infrared spectroscopy, Academic Press, New York.

19. Narang, K. K., Singh, V. P., Singh, S. K. and Mishra, G. D. 1996. Synthesis, characterization, X-ray diffraction studies and antifungal activity of cobalt(II) complexes with some aroylhydrazines. Synthesis and Reactivity in Inorganic and Metal-Organic Chemistry. 26(2): 191-209.

20. Lever, A. B. P. 1984. Inorganic electronic spectroscopy ( $2^{\text {nd }}$ Edn. $)$, Elsevier, New York.

21. Ahmed, A. H., Hassan, A. M., Gumaa, H. A., Mohamed, B. H., Eraky A. M. and Omran A. A. 2019. Copper(II)oxaloyldihydrazone complexes: Physico-chemical studies: Energy band gap and inhibition evaluation of free oxaloyldihydrazones toward the corrosion of copper metal in acidic medium. Arabian Journal of Chemistry. 12:4287-4302. 